\title{
How Scientific Attitude Like Scientists Have? A Content Analysis of the Narrative Book That Represents Stephen Hawking's Journey of Life
}

\author{
M E Simbolon ${ }^{1}$, A Acesta ${ }^{2}$, Y K Adi ${ }^{3}$, and S. Arifin ${ }^{4}$ \\ Department of Primary School Teacher Education, Kuningan University, Indonesia \\ \{marlina@uniku.ac.id\}
}

\begin{abstract}
Scientific attitude is part of scientific literacy. Students can study scientific attitude by using the life story of a scientist. This study aims to describe the scientific attitude content in a narrative book that represents Stephen Hawking's life journey. The subjects of this research are documents about Stephen Hawking's life published in Indonesia. Scientific attitude that has been studied in terms of theory relevance is the object of this study. Therefore, this study is classified as a content analysis research design. The data collection techniques in this study are The content analysis technique itself is through reading and recording. The data analysis technique used in this study is through unitizing, sampling, recording, reducing, inferring, and narrating steps. The results showed that the findings of objectivity, critical mindedness, open mindedness, curiosity, respect for evidence, and honesty were spread across the three books (MBH, WPSH, and TtI) which represented Stephen Hawking's life journey. Students in science class can learn scientific attitude through real examples in everyday life. Therefore, teachers need to facilitate students with different understanding of science in order to understand the context of each event in the story. Recommendations for future research can be discussed further on the importance of reading stories on scientific literacy
\end{abstract}

Keywords: Stephen Hawking; stories; books

\section{Introduction}

Scientific attitude becomes something important in the development of scientific literacy in students (Yaşar \& Anagün, 2009). Apart from the results of science education in the domain of knowledge and skills, the domain of attitudes is also an important outcome that students must have. Students must understand that science always contributes to life, not just knowledge without orientation (Mukhopadhyay, 2014). In this case, the learning experience must be chosen based on the attitude that must be learned. The attitudes possessed by students will influence their behavior both at school and in the community. Therefore, learning about this attitude must be carefully identified and planned. Reading can be defined as the activity of recognizing words correctly and finding information in the text. Although it may seem simple, reading is actually a constructive process.

Reading is an investigative activity, in which students analyze, criticize, and interpret the text and then deduce meaning by integrating text information with relevant background knowledge. The developmental age of elementary school students has been able to develop to start reading science critically. But in fact, it is revealed that science learning which is associated with reading activities is still very little found in elementary schools (Norris et al., 
2008). Scientific attitude concerns the desire to know and understand, question all statements, look for data and their meanings, seek verification, and consider consequences. The discussion in this study is about the attitudes that scientists have in finding and developing new knowledge, for example being objective towards facts, careful, responsible, open-minded, always wanting to observe, etc. (Dwianto, Wilujeng, Prasetyo, \& Suryadarma, 2017; Pradhan, 2015).

The active involvement of students in exploring a world that resembles the workings of scientists is an effort to reform science education. It is important for students to understand how scientists construct, evaluate, and apply scientific knowledge in the context of scientific investigation (Korkmaz, 2011). Students will understand that doing work in science requires an attitude known as a scientific attitude. This is also important for them to have. Therefore, the quality of education provided in schools, especially primary schools, has an important role in the development and progress of society.

Researchers summarize several studies that have examined the scientific attitude (Blalock et al., 2008; Kozlow \& Nay, 1976; Pitafi \& Farooq, 2012; Pradhan, 2015; Reid, 2006; Sardinah, Tursinawati, \& Noviyanti, 2012; Suryawati, Osman, \& Meerah, 2010; Widodo \& Wuryastuti, 2007; Wiwin \& Kustijono, 2018; Yaşar \& Anagün, 2009). The researcher analyzed then synthesized to find a common view so that it could be used in this study. The researcher summarized the scientific attitude content based on the theorists' tendencies and analyzed opinions consisting of aspects of objectivity, critical mindedness, open mindedness, curiosity, respect for evidence, and honesty.

Each of these aspects has its own sub-aspects which are defined as: (a) Objectivity; Not affected by self-bias in collecting and interpreting ideas, Considering all data before making decisions, Reporting as is and not manipulating data; (b) Critical Mindedness; Looking for evidence and arguments that support or contradict explanations, Looking for clarity of statements or questions to conclusions, Trying to obtain correct information; (c) Open Mindedness; Willing to change his mind in the face of reliable evidence, Respect the point of view of others; (d) Curiosity; Exploring objects by seeing, hearing, looking, listening, Asking questions about natural phenomena, Collecting as much data as possible before making conclusions; (e) Respect for Evidence; Respect the facts and try to behave in accordance with the facts, Rely on facts in making decisions; and (f) Honesty; Report observations honestly, Always refer to the truth. All these aspects and sub aspects are used as an analysis knife to achieve a deeper understanding.

So that science learning can build a scientific attitude, teachers can try to introduce students to the life of a scientist. This can be found in reading books, such as biographies. In several research studies, (Dagher \& Ford, 2005) revealed that the use of science literature for children in learning is highly recommended by science and literacy teachers. Students are very interested in this because it is relevant to their lives. Teachers can use scientist biographies as additional sources of reading to increase students' understanding of science. However, teachers need to pay attention to the potential advantages and disadvantages of using these biographies for the purpose of increasing student understanding. For example, teachers need to simplify the language used to make it relevant for primary schools.

Based on the introduction that has been described, attention is given to the analysis of the contents of a narrative textbook about the life journey of a scientist. Researchers study that the life of scientists is inseparable from the scientific attitude they have when working in the field of science. In this study, researchers limited only one scientist, namely Stephen Hawking (1942-2018). First, Hawking is a scientist who is a reference in the field of Science and holds the title of Lucasian Professor (Kirk \& Collins, 2018). Second, his biography can easily be 
found in bookstores in Indonesia. This research is also limited to the content of the book. However, the researcher assumes that when the results of this analysis are achieved, it is hoped that they will become a consideration for the teacher to use them in classroom learning.

\section{Method}

This research is classified as a content analysis research design (Krippendorff, 2004). The technique of collecting data in research is through reading and recording. The researcher reads the three books carefully and repeatedly. The notes are made in the form of data tabulations, meaning that the researcher measures the proportion of data findings related to the aspects under study of each book. Finally, the researcher conducts an analysis. to findings based on qualitatively relevant theory. Researchers collected documents about the life of Stephen Hawking ( $\mathrm{SH}$ ) published in Indonesia. At least three documents were found and researched. My Brief History (MBH) is an autobiographical book (S. Hawking, 2017). Meanwhile, the book Why? People - Stephen Hawking (WPSH) is a history of his life in comic form (Grimnamu, 2014). Finally, the book Traveling to Infinity (TtI) is a story of his personal experience (J. Hawking, 2015). Scientific attitude which has been studied in terms of theory relevance is the object of this research.

Content analysis research uses certain techniques in analyzing data. The researcher describes the data analysis technique based on a scheme (Krippendorff, 2004) which includes: (a) Unitizing, the researcher examines the communication text which is the content in the three books analyzed; (b) Sampling, the researcher focuses only on aspects that are in accordance with the research question, namely objectivity, critical mindedness, open mindedness, curiosity, respect for evidence, and honesty; (c) Recording, the researcher reads and records then categorizes and calculates the findings; (d) Reducing, summarizing similar data, focusing more thoroughly on the scientific attitude load, and possibly removing unnecessary data because it is irrelevant; (e) Inferring, the researcher analyzes the data by looking for meaning, namely explaining the findings, representing them, and explaining how students learn them; and (f) Narrating, the researcher narrates by explaining the meaning of the findings and elaborating on the relevant theory.

\section{Result and Discussion}

The results showed the spread of scientific attitude in the three books. In general, there were 12 findings on the aspect of objectivity from the three books. In the aspect of Critical Mindedness there were 31 findings from the three books. Meanwhile, on the aspect of Open Mindedness there were 23 findings. Furthermore, on the Curiosity aspect there were 30 findings. Then on the aspect of Respect for Evidence there were 21 findings. In the Honesty aspect, there are 7 findings. The following are the distribution of the findings in the three books.

Table1. Scientific Attitude in Three Books; MBH, WPSH, \& TtI

\begin{tabular}{llllll}
\hline No & Aspect & Indicator & \multicolumn{3}{c}{ Total Findings } \\
\cline { 3 - 6 } & \multirow{3}{*}{ Objectivity } & & $\mathrm{MBH}$ & $\mathrm{WPSH}$ & $\mathrm{TtI}$ \\
& & $\mathrm{O} 1$ & 1 & 2 & 4 \\
& & $\mathrm{O} 2$ & 1 & - & - \\
\hline
\end{tabular}




\begin{tabular}{|c|c|c|c|c|c|}
\hline \multirow{4}{*}{2.} & & O3 & 2 & - & 1 \\
\hline & \multirow[t]{3}{*}{ Critical Mindedness } & CM1 & 6 & 2 & 2 \\
\hline & & CM2 & 9 & - & 8 \\
\hline & & CM3 & 3 & - & 1 \\
\hline \multirow[t]{2}{*}{3.} & \multirow[t]{2}{*}{ Open Mindedness } & OM1 & 7 & 2 & 10 \\
\hline & & OM2 & 1 & 1 & 3 \\
\hline \multirow[t]{3}{*}{4.} & \multirow[t]{3}{*}{ Curiosity } & $\mathrm{C} 1$ & 6 & 8 & 7 \\
\hline & & $\mathrm{C} 2$ & 5 & 2 & 2 \\
\hline & & $\mathrm{C} 3$ & - & 1 & - \\
\hline \multirow[t]{2}{*}{5.} & \multirow[t]{2}{*}{ Respect for Evidence } & RE1 & 2 & 5 & 4 \\
\hline & & RE2 & 3 & 2 & 5 \\
\hline \multirow[t]{2}{*}{6.} & Honesty & H1 & 1 & 1 & 1 \\
\hline & & $\mathrm{H} 2$ & 2 & - & 2 \\
\hline
\end{tabular}

SH's scientific attitude contained in the three books (MBH, WPSH, and TtI) spreads across all indicators from six aspects. Although, the distribution is not evenly distributed. This is not a concern considering book publishers do not directly aim to develop books with scientific attitude integration. Therefore, this study seeks to analyze more deeply and describe the scientific attitude content so that it can be developed into learning. The following shows the reduction in findings from the scientific attitude aspect.

Figure 1. Examples of Objectivity Aspects Findings

RP : Stephen, didn't you start out with great respect and admiration
for Fred Hoyle as the best cosmological scientist?
SH : Yes. But, even though you have used any formula, this theory
still has a weak point mathematically.
(WPSH/O1/102/2)

Figure 2. Examples of Finding Aspects of Critical Mindedness

Colleague1: What? The theory that the Professor once put forward is wrong?

SH: Piiiik! I have to correct the theory about black holes that I put forward 30 years ago. Piiikkk! At that time, I said that the black hole was emitting very small substances out. Colleague1: But?

SH: I also said that black holes are not really black... At that time, I was talking like that because I didn't know the exact information about the substances that the black hole sucked up.

(WPSH/OM1/151/2)

Figure 3. Examples of Findings from Open Mindedness Aspects

SH's friend1: Isn't that Stephen?

SH's friend2: It's amazing, he grows up in the library.

SH's friend1: If a child like him has decided to study, then there will be no place for children like us.

SH's friend2: Right. The two of us who have been here for a week have yet to solve a single problem. He really is a monster. Because you can answer all the questions in just a few hours and alone too!

(WPSH/CM1/81/1) 
Figure 4. Examples of Finding the Curiosity Aspects

Edward, who has been handsome and charming since the age of eight, had a hard time getting in touch with his adoptive family when I first met the Hawkings - perhaps because they used to bring reading material to the dinner table and ignored all non-nerds. $(\mathrm{TtI} / \mathrm{C} 1 / 4 / 1)$

Figure 5. Examples of Findings for Respect for Evidence Aspects

My physical constraints are not a serious obstacle in scientific work. In fact, in some ways I consider my situation an advantage: I don't have to teach undergraduate students, and I don't have to be on various committees that are boring and timeconsuming. So I can devote myself completely to research. $(\mathrm{MBH} / \mathrm{RE} 1 / 165 / 2)$

Figure 6. Examples of Findings for Honesty Aspects

He would apologize for not being able to bring a four-dimensional model of the universe to his office to demonstrate his theory, or when asked about infinity, he would reply that it was difficult to talk about because it was so long. evidently he will get a Nobel prize. $(\mathrm{TtI} / \mathrm{H} 1 / 311 / 1)$

Based on the results of the content analysis regarding SH's scientific attitude in the three books (MBH, WPSH, and TtI), it can be interpreted that objectivity, critical mindedness, open mindedness, curiosity, respect for evidence, and honesty can be learned by students in various lessons. First, to understand the attitude of objectivity, students can learn by making reports from observations in the field according to facts and avoiding manipulation. Second, to learn critical mindedness, students can learn by solving mathematical problems or problem solving.

Third, the open mindedness of students can learn by means of self-reflection through selfassessment through peer discussion. Fourth, the curiosity attitude can be built by means of students from reading frequently to observing natural phenomena and asking questions about these phenomena. Fifth, to understand the importance of respect for evidence, students can understand scientists' stories about their experiences in applying science in the context of life. Sixth, it is the same as the fifth, apart from being able to build honesty through honesty in reporting observational data, it can also be learned from the character's story. In the end, the whole scientific attitude mentioned above cannot be manifested in every student before learning it through the life story of a famous scientist, $\mathrm{SH}$.

Therefore, it is very important to read stories that have implications for scientific literacy. Seeing this opportunity, story-based science learning is very likely to broaden the picture of science and scientists to students in elementary schools. Stories in biographies can be presented, but need to pay attention to simplification of language and perhaps focused content. When this content analysis is complete, the teacher may can develop appropriate learning strategies using this content resource.

Therefore, (Mukhopadhyay, 2014) teachers must understand the conceptual framework, how to measure, and improve the scientific attitude of their students so that they can make the quality of science learning in their class. The teacher must understand this. Basically (Widowati, Nurohman, \& Anjarsari, 2017), teachers realize that a scientific attitude is important, but they do not get enough attention for learning objectives. This makes scientific attitudes often neglected because teachers also face difficulties in designing strategies or 
learning approaches to improve scientific attitudes and document the learning outcomes of scientific attitudes.

\section{Conclusion}

Based on the results of research on scientific attitude content in the three books (MBH, WPSH, and TtI) which represent Stephen Hawking's life journey, it can be concluded that objectivity, critical mindedness, open mindedness, curiosity, respect for evidence, and honesty can be learned by students. in various studies. The overall findings of the scientific attitude content in this study cannot be manifested in every student before learning them through the life story of a scientist. Even though, the teacher's help is needed in facilitating students with different understanding of science in order to understand the context of each event in the story. Researchers are trying to get closer to understanding the importance of reading stories which, in this case, may have implications for scientific literacy. This requires further research.

\section{References}

[1] Acesta.A. (2017). Upaya mengembangkan Literasi sains Menggunakan Model SETS (Science Environment Technology Sosiety) dalam Pembelajaran Konsep Dasar IPA. Pedagogi:Jurnal Penelitian Pendidikan 4(1).

[2] [2] Blalock, C. L., Lichtenstein, M. J., Owen, S., Pruski, L., Marshall, C., \& Toepperwein, M. A. (2008). In pursuit of validity: A comprehensive review of science attitude instruments 1935-2005. International Journal of Science Education, 30(7), 961-977. https://doi.org/10.1080/09500690701344578

[3] Dagher, Z. R., \& Ford, D. J. (2005). How are scientists portrayed in children's science biographies? Science and Education, 14(3-5), 377-393. https://doi.org/10.1007/s11191-004-7933-2

[4] Dwianto, A., Wilujeng, I., Prasetyo, Z. K., \& Suryadarma, I. G. P. (2017). The development of science domain based learning tool which is integrated with local wisdom to improve science process skill and scientific attitude. Jurnal Pendidikan IPA Indonesia, 6(1), 23-31. https://doi.org/10.15294/jpii.v6i1.7205

[5] Eliyanti, M. (2018). Pengembangan Pembelajaran Aktif Menggunakan Metode Pembelajaran Berbasis Proyek (PjBL) dalam Pembelajaran Bahasa Sastra Indonesia di Kelas Rendah. Pedagogi:Jurnal Penelitian Pendidikan, 5(1)

[6] Grimnamu. (2014). Why? people - stephen hawking. Jakarta: PT Elex Media Komputindo.

[7] Hawking, J. (2015). Travelling to infinity. Jakarta: PT Gramedia Pustaka Utama.

[8] Hawking, S. (2017). My brief history. Jakarta: PT Gramedia Pustaka Utama.

[9] Korkmaz, H. (2011). The Contribution of Science Stories Accompanied by Story Mapping to Students' Images of Biological Science and Scientists. Electronic Journal of Science Education, 15(1), 1-41. Retrieved from http://ejse.southwestern.edu

[10] Kozlow, M. J., \& Nay, M. A. (1976). An approach to measuring scientific attitudes. Science Education, 60(2), 147-172. https://doi.org/10.1002/sce.3730600203

[11] Krippendorff, K. (2004). Content analysis: an introduction to its methodology 2nd ed. Thousand Oaks: Sage Publications Inc.

[12] Lismaya, I (2017) Pengaruh Model Pembelajaran Berbasis Masalah terhadap Kemampuan Berpikir Kritis Mahasiswa pada Konsep Spesiasi. Quagga Jurnal Pendidikan dan Biologi, 9(1), 73-80

[13] Mukhopadhyay, D. R. (2014). Scientific attitude - some psychometric considerations. IOSR Journal of Humanities and Social Science, 19(1), 98-100. https://doi.org/10.9790/0837-191798100 
[14] Norris, S. P., Phillips, L. M., Smith, M. L., Sandra, M., Stange, D. M., Baker, J. J., ... Al, N. E. T. (2008). Learning to Read Scientific Text: Do Elementary School Commercial Reading Programs Help ? Science Education, (2004). https://doi.org/10.1002/sce.20266

[15] Pitafi, A. I., \& Farooq, M. (2012). Measurement of Scientific Attitude of Secondary School Students in Pakistan. Academic Research International, 2(2), 379-392. https://doi.org/10.1002/mrm.24433

[16] Pradhan, B. K. (2015). A Comparative Study of Scientific Attitude among Students of English and Odia Medium Schools at Secondary Level. Global Journal of Engineering, Science \& Social Science Studies, 01(02), 102-110.

[17] Reid, N. (2006). Thoughts on attitude measurement. Research in Science \& Technological Education, 24(1), 3-27. https://doi.org/10.1080/02635140500485332

[18] Sardinah, Tursinawati, \& Noviyanti, A. (2012). Relevansi Sikap Ilmiah Siswa dengan Konsep Hakikat Sains dalam Pelaksanaan Percobaan pada Pembelajaran IPA di SDN Kota Banda Aceh. Jurnal Pendidikan Serambi Ilmu, 13, 70-80.

[19] Suparman, I.W., Eliyanti, M., \& Hermawati, E. (2020). Pengaruh Penyajian Materi dalam Bentuk Media Komik terhadap Minat Baca dan Hasil Belajar. Pedagogi: Jurnal Penelitian Pendidikan 7(1)

[20] Suryawati, E., Osman, K., \& Meerah, T. S. M. (2010). The effectiveness of RANGKA contextual teaching and learning on student's problem solving skills and scientific attitude. Procedia - Social and Behavioral Sciences, 9, 1717-1721. https://doi.org/10.1016/j.sbspro.2010.12.389 